\title{
SYRINGOCYSTADENOMA PAPILLIFERUM: A RARE TUMOR IN AN UNUSUAL LOCATION
}

\author{
Jelena ROGANOVIĆ ${ }^{1}$, Ela BRGODAC ${ }^{1}$, Nives JONJIĆ
}

\author{
${ }^{1}$ Department of Pediatrics, Clinical Hospital \\ Center Rijeka, Croatia, ${ }^{2}$ Department of \\ Pathology and Pathological Anatomy \\ School of Medicine, University of Rijeka \\ Rijeka, Croatia \\ Corresponding author: \\ Roganović Jelena \\ Clinical Hospital Center Rijeka \\ Istarska 43, 51000 Rijeka \\ jelena.roganovic1@ri.t-com.hr \\ Tel.: + $38551659103 / 109$ \\ Fax.: + 38551623126
}

Received: July 27, 2014

Accepted: November 1, 2014

Copyright (C) 2015 by

University Clinical Centre Tuzla.

E-mail for permission to publish:

paediatricstoday@ukctuzla.ba
Objective - To report a very rare case of syringocystadenoma papilliferum, describing its clinical presentation, histopathological appearance and surgical management. Case report - An 11-year-old girl presented with a partially lobulated linear plaque on her right lower back present since birth, which was clinically diagnosed at first as linear epidermal nevus. The tumor was surgically removed. The histopathology confirmed the diagnosis of syringocystadenoma papilliferum. Conclusion - Syringocystadenoma papilliferum is a benign adnexal tumor that occurs most often in the head and neck. The tumor has characteristic histological features, and varied and non-distinct clinical findings. Although extremely rare, this lesion should be considered in the differential diagnosis of skin tumors in children.

Key words: Syringocystadenoma papilliferum - Skin hamartoma Child.

\section{Introduction}

Syringocystadenoma papilliferum (SCAP) is a very rare benign hamartomaous skin tumor. Its exact histogenesis remains unclear, and possible apocrine, eccrine or apoeccrine origin has been broadly debated (1). Tumors are usually seen at birth or appear during childhood and tend to proliferate around puberty (2). SCAP may occur de novo or within a nevus sebaceous. The majority of patients present with a solitary lesion in the head and neck region (2). The localization over abdomen is rare, and only seven cases have been published in the literature. We report an unusual case of SCAP presenting on the back.

\section{Case report}

An 11-year-old girl presented with a discrete pink-colored superficial, occasionally pruritic lesion on the right lower back. The lesion had been present since birth, and no significant change in size or general appearance was noted in the following years. A physical examination revealed a solitary, $1,5 \times 1 \mathrm{~cm}$ in size hairless plaque, with partially lobular structure. The clinical suspicion was a linear epidermal nevus. There were no associated systemic symptoms. The routine hematological and biochemical tests were normal. The patient was referred to the pediatric surgeon for complete excision. Histopatho- 

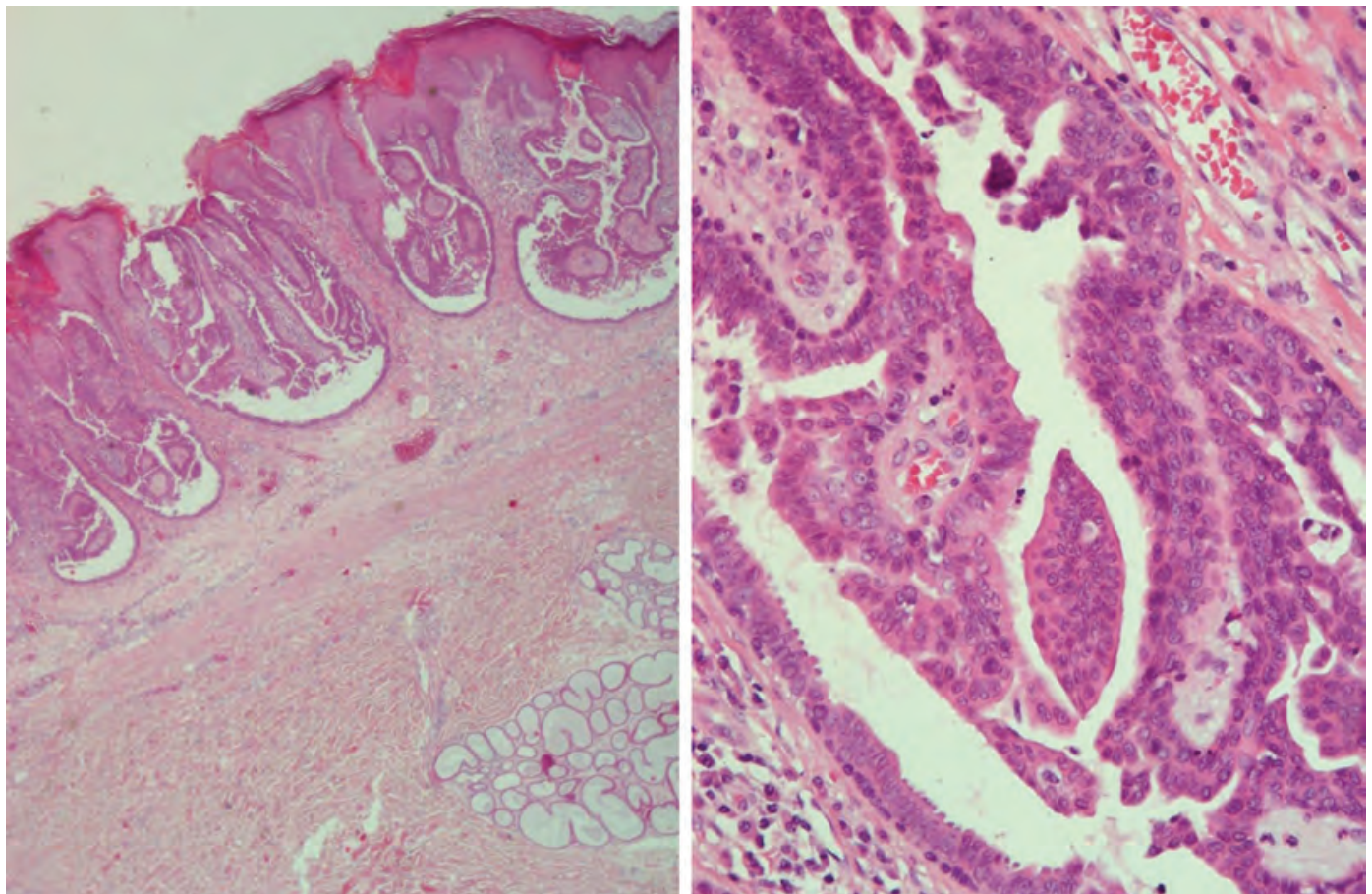

Fig. 1 Syringocystadenoma papilliferum: (A) invaginations from the overlying epidermis (B) fulfilled with papillae, covered with a luminar layer of tall columnar cells and the inner layer of small myoepithelial cells with byperchromatic nuclei.

logic examination (Fig. 1) demonstrated cystic invagination of epidermis with papillary proliferation. Papillae were mostly lined by multilayer squamous epithelium, with inner row of small myoepithelial cells and columnar cells in the outer layer. Glandular formations were interspersed in epithelium. The fibrovascular core of the papillae showed plasmacellular inflammatory infiltrate. The underlying deep dermis showed two cystic enlarged channels. Slightly hyperplastic, hyperkeratotic and parakeratotic epithelium was located peripherally. These findings were consistent with the diagnosis of SCAP. The postoperative period was uneventful. At oneyear follow-up, the girl is doing well with no evidence of local recurrence.

\section{Discussion}

SCAP is an uncommon benign hamartomatous adnexal tumor. The histogenesis remains unclear, and the results of immunohistochemistry and electron microscopy have been conflicting (4). It was postulated that SCAP arises from a pluripotent cells with the potential to exhibit either apocrine or eccrine differentiation, but there is an increasing evidence for an apocrine origin (1). Three clinical types have been described. It may present as a solitary nodule (solitary nodular form), a nodular hairless plaque (plaque type), or as a linear group of brownish or erythematous papules or nodules (linear type) (3). The tumor varies in size from 5 to $160 \mathrm{~mm}$ (5). The surface can be smooth, flat, papillomatous, or verrucous. Most of the patients present with solitary lesions. Multiple lesions are usually associated with naevus sebaceous (3, 5). SCAP is also associated with linear naevus verrucosus, apocrine poroma, apocrine hidrocystoma, tubulopapillary hidradenoma, hidradenoma papilliferum, papillary eccrine adenoma, apocrine acrosyringeal keratosis, 
poroma folliculare, linear naevus verrucosa, atypical fibroxanthoma, clear cell syringoma, basal cell epithelioma, sebaceous epithelioma, trichoepithelioma, verruca vulgaris, and naevus comedonicus. The most common associated lesion is nevus sebaceous $(31,7 \%)$, followed by basal cell epithelioma (10,3\%), sebaceous epithelioma (3,2\%), apocrine hidrocystoma (3,2\%), trichoepithelioma $(1,6 \%)$, and eccrine spiradenoma $(0,8 \%)(6)$.

In contrast to a widely variable clinical appearance, the histopathology is uniform and confirmatory. SCAP is characterized by cystic invaginations extending downwards from the epidermis. The upper regions of the cystic invaginations are commonly lined by keratinizing squamous epithelial cells. The lower regions, which contain numerous papillary projections, are lined by glandular epithelium consisting of two rows of cells: a luminar layer of high columnar cells frequently demonstrating "decapitation" secretion (characteristic of the secretory cells of the apocrine sweat glands), and a basal layer of small cuboidal cells with strongly basophilic nuclei. The connective tissue stroma within the papillary projections is marked by rich infiltration of inflammatory cells; most notably there is a large number of plasma cells.

Almost half of the tumors are present at birth or appear during infancy. The lesion usually increases in size at puberty, becoming papillomatous and crusted. The great majority of SCAP occur in the head and neck area. Mammino et al. reviewed 145 cases of SCAP and found 108 cases $(75 \%)$ on the head and neck, 29 cases $(20 \%)$ on the trunk, and 8 cases $(5 \%)$ on the extremities (2). However, over last two decades there are increasing reports of SCAP occurring in unusual locations outside the head and neck region (7).

Malignant transformation may occur. Basal cell carcinoma development has been reported in up to $10 \%$ of SCAP, in the majority of them with coexistent nevus sebaceous.
Allelic loss at 9q22 is consistent with the clinical observation of transition of SCAP to basal cell carcinoma. Squamous cell carcinoma, verrucous carcinoma and ductal carcinoma arising from SCAP have been published (3). Syringocistadenocarcinoma papilliferum is a malignant counterpart of SCAP $(8,9)$.

The treatment of choice for SCAP is complete surgical excision. Carbon dioxide laser can be useful for lesions on anatomic sites not suitable for surgery (9). To date, there are few reported cases of SCAP of arising on the abdomen $(7,10-17)$. Our patient had an extremely rare location of the plaque type. Her tumor was present since birth and, unusual for this type of the tumor, did not change over time. There was no association with other benign adnexal lesion. Based on the appearance of the lesion and the long history, SCAP was not clinically suspected in our case. We performed a complete excision with detailed histologic examination. This case emphasizes that SCAP should be considered in the differential diagnosis of childhood adnexal tumors.

\section{Conclusion}

Solitary skin lesions in unusual locations in children have a wide array of differential diagnoses, including SCAP. The treatment of choice is a local excision with confirmatory histopathology.

Authors' contributions: Conception and design: JR; Acquisition, analysis and interpretation of data: JR, EB, NJ; Drafting the articleJR, EB, NJ; Revising it critically for important intellectual content: JR.

Conflict of interest: The authors declare that they have no conflict of interest.

\section{References}

1. Paradiso B, Bianchini E, Cifelli P, Cavazzini L, Lanza G. A new case of syringocystadenocarcinoma papilliferum: a rare pathology for a 
wide-ranging comprehension. Case Rep Med. 2014;2014:453874. doi: 10.1155/2014/453874. Epub 2014 May 15. PubMed PMID: 24959179; PubMed Central PMCID: PMC4052556.

2. Mammino JJ, Vidmar DA. Syringocystadenoma papilliferum. Int J Dermatol. 1991;30(11):763-6.

3. Katoulis AC, Bozi E. Syringocystadenoma papilliferum. Orphanet Encyclopedia. 2004 April. [cited 2014 May 10]. Available from: https://www. orpha.net/data/patho/GB/uk-Syringocystadenoma-papilliferum.pdf.

4. Yamamoto O, Doi Y, Hamada T, Hisaoka M, Sasaguri Y. An immunohistochemical and ultrastructural study of syringocystadenoma papilliferum. $\mathrm{Br}$ J Dermatol. 2002;147(5):936-45.

5. Agrawal R, Kumar R, Varshney R. Syringocystadenoma papilliferum: an unusual presentation. Journal of Clinical and Diagnostic Research [serial online] 2014 May [cited: 2014 Jul 27]; Available from: http://www.jcdr.net/back_issues.asp?issn=0973709x \&year $=2014 \&$ month $=$ May\&volume $=8$ \&issu e=5\&page=QD03-QD04\&id $=4336$.

6. Fujita M, Kobayashi M. Syringocystadenoma papilliferum associated with poroma folliculare. J Dermatol. 1986;13(6):480-2.

7. Ghosh SK, Bandyopadhyay D, Chatterjee G, Bar C. Syringocystadenoma papilliferum: an unusual presentation. Pediatr Dermatol. 2009;26(6):758-9.

8. Ishida-Yamamoto A, Sato K, Wada T, Takahashi H, Iizuka H. Syringocystadenocarcinoma papilliferum: case report and immunohistochemical comparison with its benign counterpart. J Am Acad Dermatol. 2001;45(5):755-9.
9. Hoekzema R, Leenarts MF, Nijhuis EW. Syringocystadenocarcinoma papilliferum in a linear nevus verrucosus. J Cutan Pathol. 2011;38(2):246-50.

10. Xu D, Bi T, Lan H, Yu W, Wang W, Cao F, et al. Syringocystadenoma papilliferum in the right lower abdomen: a case report and review of literature. Onco Targets Ther. 2013;6:233-6.

11. Suzuki T, Ikeda H, Hamasaki Y, Hatamochi A, Yamazaki S. Syringocystadenoma papilliferum associated with apocrine poroma. J Dermatol. 2006; 33(4):249-51.

12. Yap FB, Lee BR, Baba R. Syringocystadenoma papilliferum in an unusual location beyond the head and neck region: a case report and review of literature. Dermatol Online J. 2010;16(10):4.

13. Chauhan A, Gupta L, Gautam RK, Bhardwaj M, Gopichandani K. Linear syringocystadenoma papilliferum: a case report with review of literature. Indian J Dermatol. 2013;58(5):409.

14. Kar M, Kar JK, Maiti S. Giant linear syringocystadenoma papilliferum of the back. Indian J Dermatol Venereol Leprol. 2012;78(1):123.

15. Lee HJ, Cho E, Kim MH, Cho SH, Lee JD. Syringocystadenoma papilliferum of the back combined with a tubular apocrine adenoma. Ann Dermatol. 2011;23(Suppl 2):151-4.

16. Townsend TC, Bowen AR, Nobuhara KK. Syringocystadenoma papilliferum: an unusual cutaneous lesion in a pediatric patient. J Pediatr. 2004;145(1):131-3.

17. Monticciolo NL, Schmidt JD, Morgan MB. Verrucous carcinoma arising within syringocystadenoma papilliferum. Ann Clin Lab Sci. 2002;32(4):434-7. 